\title{
Construction of single-chain variable fragment antibodies against MCF-7 breast cancer cells
}

\author{
A.A. Zuhaida ${ }^{1}$, A.M. Ali ${ }^{1,2}$, S. Tamilselvan ${ }^{3}$, N.B. Alitheen ${ }^{3}$, \\ M. Hamid ${ }^{1,4}$, A.M. Noor ${ }^{2}$ and S.K. Yeap ${ }^{1}$ \\ ${ }^{1}$ Laboratory of Molecular Biomedicine, Institute of Bioscience, \\ Universiti Putra Malaysia, Serdang, Malaysia \\ ${ }^{2}$ Faculty of Agriculture and Biotechnology, Universiti Sultan Zainal Abidin, \\ City Campus, Jalan Sultan Mahmud, Kuala Terengganu, Malaysia \\ ${ }^{3}$ Department of Cell and Molecular Biology, \\ Faculty of Biotechnology \& Biomolecular Sciences, \\ University Putra Malaysia, Serdang, Malaysia \\ ${ }^{4}$ Department of Microbiology, Faculty of Biotechnology \& Biomolecular Sciences, \\ University Putra Malaysia, Serdang, Malaysia \\ Corresponding author: N.B. Alitheen \\ E-mail: noorjahan@biotech.upm.edu.my
}

Genet. Mol. Res. 12 (4): 5547-5559 (2013)

Received September 24, 2012

Accepted March 25, 2013

Published November 18, 2013

DOI http://dx.doi.org/10.4238/2013.November.18.5

\begin{abstract}
A phage display library of single chain variable fragment ( $\mathrm{scFv}$ ) against MCF-7 breast cancer cells was constructed from C3A8 hybridoma cells. RNA from the $\mathrm{C} 3 \mathrm{~A} 8$ was isolated, cDNA was constructed, and variable heavy and light immunoglobulin chain gene region were amplified using PCR. The variable heavy and light chain gene regions were combined with flexible linker, linked to a pCANTAB 5E phagemid vector and electrophoresed into supE strain of Escherichia coli TG1 cells. Forty-eight clones demonstrated positive binding activity to MCF-7 breast cancer cell membrane fragments and the strongest of 48 clones was selected for analysis. The anti-MCF-7 library evaluated by SfiI and NotI digests demonstrated that anti-MCF-7 scFv
\end{abstract}


antibodies possess individual patterns that should be able to recognize distinct human breast cancer cells. The $\mathrm{C} 3 \mathrm{~A} 8 \mathrm{scFv}$, with an apparent molecular weight of $32 \mathrm{kDa}$, showed high homology (99\%) with single chain antibody against rice stripe virus protein $\mathrm{P} 20$. In summary, the anti MCF-7 scFv antibody can be used for pretargeting breast cancer for clinical diagnosis of patients; it also has potential for therapeutic applications.

Key words: Recombinant antibody; scFv; C3A8; MCF-7

\section{INTRODUCTION}

The advances in antibody cloning technology have greatly facilitated the genetic manipulation of antibody fragments and permitted the development of a large variety of engineered antibody molecules for research, diagnosis and therapy (Boss et al., 1984; Kontermann and Muller, 1999). It is possible for the cloned antibodies to have improved the affinity and specificity of antigen binding by mimicking somatic hypermutation during an immune response (Gram et al., 1992). The generation of single-chain variable fragments (scFv) has become an established technique used to produce soluble antibody in bacterial systems. $\mathrm{scFv}$ are constructed mainly from hybridomas (Huston et al., 1988; Chaudhary et al., 1990), spleen cells (Chowdhury et al., 1998; Finlay et al., 2006), and also human B lymphocytes (Shadidi et al., 2001; Zhang et al., 2006). An antibody in scFv format consists of variable regions of heavy $\left(\mathrm{V}_{H}\right)$ and light $\left(\mathrm{V}_{\mathrm{L}}\right)$ chains that are joined together by a flexible peptide linker. It can be easily expressed in functional form in Escherichia coli, allowing protein engineering to improve the properties of scFv, such as increased of affinity and alteration of specificity (Griffiths and Duncan, 1998). Apart from bacteria, $\mathrm{scFv}$ have been successfully isolated and displayed as fragments in mammalian cells, yeast (Ho et al., 2006), plants (Huston et al., 1996) and insect cells (Choo et al., 2002).

In cancer treatment, radioimmunotherapy (RIT) has shown efficacy in the treatment of advanced metastatic human breast cancer, but the advantageous characteristics of tumor specificity attributed to the use of intact monoclonal antibodies is often diminished due to the increased radiation dose delivered to normal tissues during the extended time that the large antibody molecules remains in circulation. To improve RIT, various versions of genetically engineered multivalent antibodies, including diabodies and minibodies have been investigated (Hu et al., 1996; Adams et al., 1998). scFv have demonstrated to be a particularly useful tool for clinical and medical applications, since they are only half the size of fragment antibodies (Fabs) and thus have lower retention times in non-target tissue, more rapid blood clearance and better tumor penetration (Huston et al., 1996; Marasco et al., 1998). Phage displayed technology is a system that makes it possible to generate scFvs with desired binding affinity and specificities (Garet et al., 2010; Pande et al., 2010). In the present study, we demonstrated the construction of anti-MCF-7 $\mathrm{scFv}$ antibodies specific to human breast cancer cells by phage display technology.

\section{MATERIAL AND METHODS}

\section{Cell culture}

The C3A8 hybridoma cell line was prepared by immunization of a mouse with MCF-7 
breast cancer cells and hybridization of the $\mathrm{B}$ cells from the spleen of the immunized mouse with the murine myeloma cell line Sp2/0-Ag14 (Ali et al., 1996). The hybridoma cell line producing Mab (isotype $\operatorname{IgM}, \kappa)$ was used as the source for the preparation of $\mathrm{scFv}$ while MCF-7 cells were used for the preparation of antigens. Both hybridoma and MCF-7 cells were retrieved from storage in liquid nitrogen and maintained in $10 \mathrm{~mL}$ RPMI-1640 medium, supplemented with $10 \%$ heat- inactivated fetal bovine serum, $0.2 \%$ sodium bicarbonate, 100 $\mathrm{U} / \mathrm{mL}$ of penicillin and $100 \mathrm{U} / \mathrm{mL}$ streptomycin at $37^{\circ} \mathrm{C}$ in atmosphere of $5 \% \mathrm{CO}_{2}$.

\section{Amplification and cloning of the immunoglobulin $V_{H}$ and $V_{L}$ chains}

Messenger RNA was isolated from actively dividing hybridoma cells using the QuickPrep mRNA Purification kit (Pharmacia, Sweden) according to the manufacturer instructions. The purified mRNA was used for first-strand cDNA synthesis and the resulting $\mathrm{V}_{H}$ and $\mathrm{V}_{\mathrm{L}}$ chain cDNAs were amplified using a recombinant phage antibody system kit (RPAS; Pharmacia, Sweden). Amplification using $5000 \mathrm{U} / \mathrm{mL}$ AmpliTaq DNA polymerase (Perkin-Elmer Cetus, USA) was performed at $94^{\circ} \mathrm{C}$ for $30 \mathrm{~s}, 55^{\circ} \mathrm{C}$ for $1 \mathrm{~min}$ and $72^{\circ} \mathrm{C}$ for $1 \mathrm{~min}$, up to $30 \mathrm{cycles}$. Amplified DNA fragments were purified using the Sephaglas Bandprep kit (Pharmacia, Sweden).

\section{Construction of ScFv}

The purified $\mathrm{V}_{\mathrm{H}}$ and $\mathrm{V}_{\mathrm{L}}$ DNA were assembled into a $\mathrm{scFv}$ fragment using a linker DNA (Pharmacia, Sweden) and the primary amplification was performed at $94^{\circ} \mathrm{C}$ for $1 \mathrm{~min}$ followed by $63^{\circ} \mathrm{C}$ for $4 \mathrm{~min}$. The assembled $\mathrm{scFv}$ product was subsequently amplified with primers that create SfiI and NotI restriction sites by using the same program as above. Following assembly, the amplified product ( $750 \mathrm{bp}$ ) was digested with SfiI and NotI (Pharmacia, Sweden) and purified using the Sephaglas Bandprep kit (Pharmacia, Sweden).

\section{Cloning of the DNA fragments of $V_{H}$ and $V_{L}$ chains DNA into pCANTAB 5E vector}

The purified scFv with SfiI and NotI restriction sites was then cloned into a phagemid vector pCANTAB 5E (Pharmacia). Following ligation, the phagemids with the inserts were transformed into E. coli strain TG1. The transformed cells were plated onto SOBAG agar plate and incubated at $37^{\circ} \mathrm{C}$ overnight on a rocking platform at $250 \mathrm{rpm}$. After the incubation, the agar plates containing the transformants were flooded with $2 \mathrm{X}$ YT-AG medium and transferred to a 50-mL polypropylene tube (Falcon, USA). The cell suspension was diluted with 2X YT-AG medium to obtain an $\mathrm{A}_{600}$ of 0.5 and $5 \mathrm{~mL}$ cell suspension were used to rescue the recombinant phages.

\section{Rescue and selection of recombinant phages expressing the scFv}

Recombinant phages were rescued by adding the M13K07 helper phage $\left(\sim 3 \times 10^{10}\right.$ $\mathrm{PFU})$ to the cell suspension. After incubation at $37^{\circ} \mathrm{C}$ for $3 \mathrm{~h}$, cells were pelleted at $1000 \mathrm{~g} \mathrm{~g}$ and the pellet was resuspended in $2 \mathrm{X}$ YT-AK medium. The culture was incubated at $37^{\circ} \mathrm{C}$ for overnight on a rocking platform at $250 \mathrm{rpm}$. The culture was centrifuged as described above, and the supernatant containing the recombinant phages was used to select for $\mathrm{scFv}$-expressing 
clones by panning. It was performed using $25-\mathrm{cm}^{2}$ tissue culture flasks coated with MCF-7 cells $\left(1 \times 10^{6}\right.$ cells $\left./ \mathrm{mL}\right)$ as the antigen. The coated flasks were washed 3 times with PBS and fixed by $0.06 \%$ glutaraldehyde before being blocked with PBS-B (PBS with 3\% skim milk). Supernatant containing the recombinant phages was diluted with an equal volume of PBS-B and pre-incubated at room temperature for 10-15 min. After pre-incubation, the recombinant phages were added to the antigen-coated flasks and incubated at $37^{\circ} \mathrm{C}$ for $2 \mathrm{~h}$. The flasks were washed vigorously with PBS-T (PBS with $0.05 \%$ Tween-20). After the washings, log phase $E$. coli strain TG1 in $2 \mathrm{X}$ YT medium was added to the flasks. Cells were incubated at $37^{\circ} \mathrm{C}$ for 1 $\mathrm{h}$ and then serially diluted tenfold dilution were carried out with $2 \mathrm{X}$ YT medium. An aliquot of the dilution was spread onto SOBAG agar plates and incubated at $30^{\circ} \mathrm{C}$ overnight.

\section{DNA sequencing}

The DNA region encoding the $\mathrm{scFv} \mathrm{C} 3 \mathrm{~A} 8$ antibody gene was sequenced using pCANTAB 5E sequencing primer set by automated DNA sequencing systems (FIRST BASE Laboratories Sdn. Bhd, Malaysia). Single-strand DNA (ssM13 DNA) was prepared with a QIAprep M13 purification kit according to manufacturer protocol while the double-strand DNA was prepared using the PureLink ${ }^{\mathrm{TM}}$ Quick Plasmid Miniprep kit according to the manufacturer protocol.

\section{Second rescue of recombinant phages}

Well-isolated colonies on the SOBAG agar plates were transferred to separate wells of a 96-well microtiter plate (Nunc, Denmark) containing $400 \mathrm{~mL}$ of $2 \mathrm{X}$ YT-AG medium. The microtiter plate was incubated at $30^{\circ} \mathrm{C}$ overnight on a rocking platform at $250 \mathrm{rpm}$. The overnight culture about $40 \mathrm{~mL}$ was added to $2 \mathrm{X}$ YT-AG medium containing $1.0 \times 10^{8} \mathrm{PFU}$ of M13K07 helper phage, and the plate was incubated at $37^{\circ} \mathrm{C}$ for $2 \mathrm{~h}$ on a shaker at 150 $\mathrm{rpm}$. After the incubation, the microtiter plate was centrifuged at $1500 \mathrm{~g}$ for $20 \mathrm{~min}$ and the supernatant was removed. Fresh 2X YT-AK medium was added and samples were incubated overnight at $37^{\circ} \mathrm{C}$ with constant shaking. The bacterial cells were pelleted at $1500 \mathrm{~g}$ for $20 \mathrm{~min}$ and the supernatant containing the recombinant phages was removed.

\section{Production of scFv}

The supernatant consisting of the antigen-binding recombinant phages was added to $\log$ phase E. coli strain $\mathrm{HB} 2151$ in $2 \mathrm{X}$ YT-medium and incubated at $37^{\circ} \mathrm{C}$ for 30 min with intermittent gentle shaking. At the end of incubation, the culture was streaked onto a SOBAG$\mathrm{N}$ plate containing $100 \mu \mathrm{g} / \mathrm{mL}$ naladixic acid and incubated at $30^{\circ} \mathrm{C}$ for overnight. A single colony of infected $E$. coli strain HB2151 on SOBAG-N was picked and grown overnight at $30^{\circ} \mathrm{C}$ in $2 \mathrm{X}$ YT-AG medium containing $100 \mu \mathrm{g} / \mathrm{mL}$ ampicillin and $2 \%$ glucose. The overnight culture was diluted 1:10 with fresh $2 \mathrm{X}$ YT-AG medium and incubated at $30^{\circ} \mathrm{C}$ for an hour. After incubation, the culture was centrifuged at $1500 \mathrm{~g}$ for $20 \mathrm{~min}$ and the supernatant was discarded. The pellet was then resuspended in $2 X$ YT-AI medium containing $100 \mu \mathrm{g} / \mathrm{mL}$ ampicillin and $1 \mathrm{mM}$ of isopropyl $\beta$-D-1-thiogalactopyranoside, and the cell suspension was incubated for additional $5 \mathrm{~h}$. At the end of the incubation, the bacterial pellet was divided into two separate $50-\mathrm{mL}$ centrifuge tubes prior to centrifugation. One pellet was resuspended in 
$0.5 \mathrm{~mL}$ of ice-cold $1 \mathrm{X}$ TES and the supernatant containing scFv antibody from the bacterial periplasm was collected by centrifugation. For preparation of the whole cell extract, $0.5 \mathrm{~mL}$ of PBS was added to the second pellet and the suspension boiled for $5 \mathrm{~min}$ and centrifuged. The supernatant containing $\mathrm{scFv}$ was collected and stored at $-20^{\circ} \mathrm{C}$ until used.

\section{Electrophoresis and immunoblotting}

The samples were loaded into sodium dodecyl sulfate (SDS) polyacrylamide gel and run at $100 \mathrm{~V}$ for $90 \mathrm{~min}$. The gel was stained with Coomassie blue $(0.1 \%$ Coomassie blue, $40 \%$ methanol and $10 \%$ glacial acetic acid) and destained with $10 \%$ methanol and $10 \%$ glacial acetic acid buffer overnight. The protein gel was transferred to a polyvinylidene difluoride membrane (Immobilon-P, Millipore Corp., USA) for Western blot analysis using a semi-dry electroblotting system (Bio-Rad Laboratories, USA) for $45 \mathrm{~min}$ at $15 \mathrm{~V}$ in transfer buffer [25 $\mathrm{mM}$ Tris base, $192 \mathrm{mM}$ glycine, and 20\% (w/v) methanol]. The membrane was blocked with $1 \%$ bovine serum albumin in PBS for one hour and washed in $0.05 \%$ Tween 20 in PBS. The membrane was then incubated with anti E-tag horseradish peroxidase (HRP)-conjugated goat anti-mouse antibody (Amersham Pharmacia Biotech, AB) at 1:1000 at room temperature for $30 \mathrm{~min}$. The conjugate was prepared in blocking buffer containing $100 \mathrm{mM}$ Tris and $150 \mathrm{mM}$ $\mathrm{NaCl}$. The membrane was washed, and 4-chloro-1-napthol (SIGMA, USA) was then added onto the membrane. After 5 min of incubation, distilled water was added to stop the reaction and the bands were documented using Kodak film.

\section{Detection of scFv antibody by ELISA}

The indirect ELISA was carried out to determine the concentration of $\mathrm{scFv}$ antibodies. Initially, MCF-7 cells at a concentration of $1 \times 10^{6}$ cells $/ \mathrm{mL}$ were seeded in 96 -well plates and incubated overnight at $37^{\circ} \mathrm{C}$ in a $5 \% \mathrm{CO}_{2}$ incubator. The plates were washed with PBS and fixed with $0.06 \%$ glutaraldehyde before being blocked with PBS containing $2 \%$ BSA for $2 \mathrm{~h}$ at $37^{\circ} \mathrm{C}$. Each well was rinsed thrice PBS containing Tween 20 and loaded with $100 \mu \mathrm{L}$ of scFv from both supernatant and periplasmic extract. The plain 2YT medium served as the negative control and incubated for $1 \mathrm{~h}$ at room temperature. After rinsing three times with PBS containing Tween 20, HRP-conjugated anti-E tag antibody (Amersham Pharmacia Biotech, AB) was added. The conjugate was diluted in washing buffer at 1:100, 1:200, 1:500, 1:1000 1:2000 and 1:4000 dilutions. Finally, $100 \mu \mathrm{L}$ of substrate solution were applied onto each well and the plates incubated for $50 \mathrm{~min}$ at room temperature. The plates were read at $405 \mathrm{~nm}$ in an ELISA auto-reader (Bio-Tek Instruments, Inc., Winooski, VT, USA).

\section{RESULTS}

\section{Construction of single-chain fragment variable antibodies}

The mRNA was isolated from the hybridoma line C3A8 and cDNA synthesis was performed. The whole cDNA reaction mixture was used for PCR amplification of the variable light and heavy chain genes. The light and heavy chains generated a sharp band at around 340 and $320 \mathrm{bp}$, respectively, as predicted. The antibody heavy and light chain DNAs were subse- 
quently joined into a scFv by a $\left(\mathrm{Gly}_{4} \mathrm{Ser}\right)_{3}$ linker sequence. The amplified $\mathrm{scFv}$ was measured around 750 bp (Figure 1).

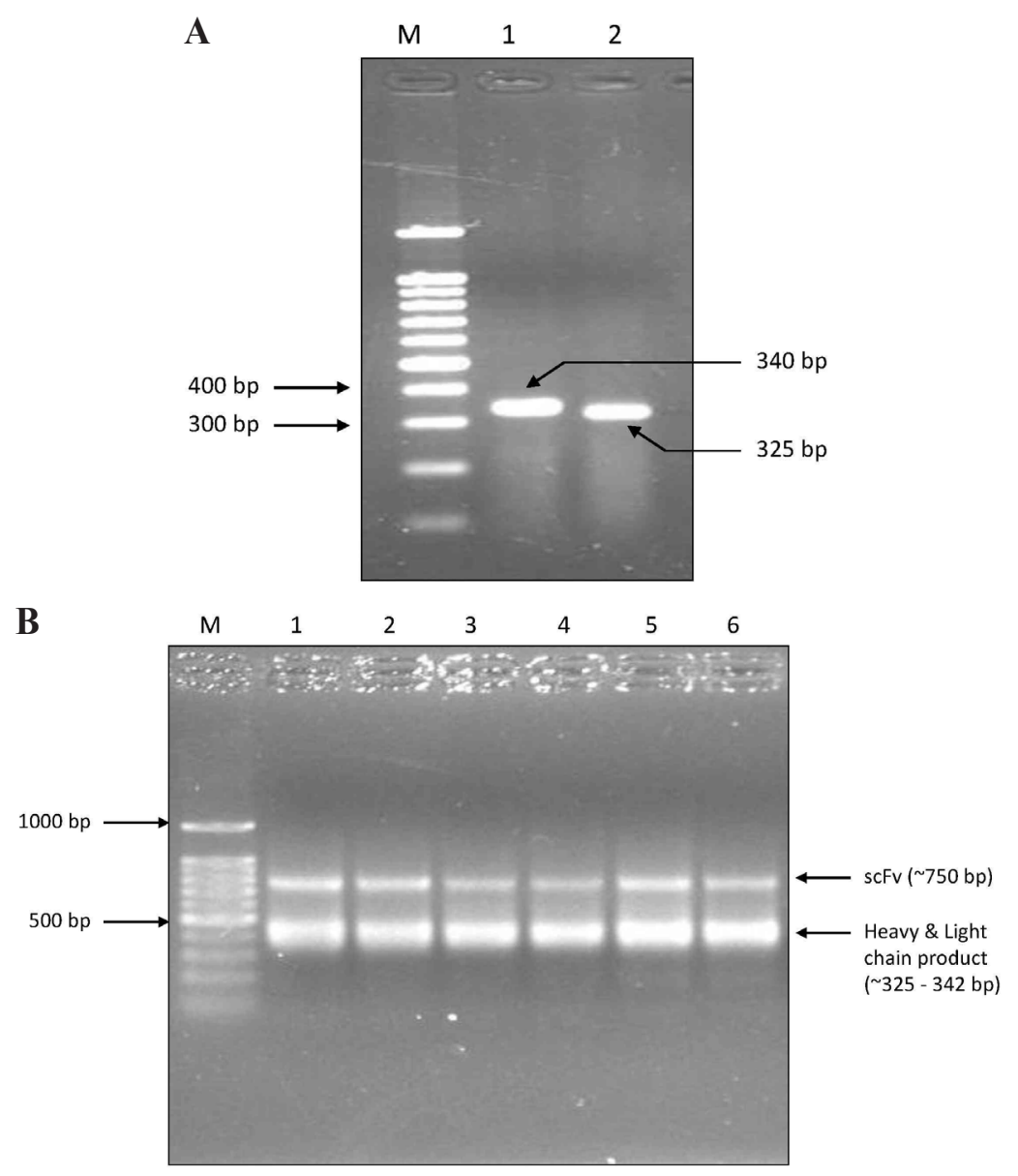

Figure 1. A. Amplification of the variable heavy $\left(\mathrm{V}_{\mathrm{H}}\right)$ and variable light $\left(\mathrm{V}_{\mathrm{L}}\right)$ chain genes from the cDNA of hybridoma cell line $\mathrm{C} 3 \mathrm{~A} 8$. A 3- $\mu \mathrm{L}$ aliquot of the amplified $\mathrm{V}_{\mathrm{H}}$ (lane 1) and $\mathrm{V}_{\mathrm{L}}$ (lane 2) products were electrophoresed on a $1.2 \%$ agarose gel in $0.5 \mathrm{X}$ TAE and stained with ethidium bromide. The amplified $\mathrm{V}_{\mathrm{H}}$ and $\mathrm{V}_{\mathrm{L}}$ DNAs were about 340 bp and 325 $\mathrm{bp}$, respectively. B. Amplification of the assembled single chain fragment variable ( $\mathrm{scFv}$ ). Twenty-five microliters of the amplified scFv products (lanes 1 to 6 ) were electrophoresed on a $1.0 \%$ agarose gel in $0.5 \mathrm{X}$ TAE and stained with ethidium bromide. The amplified scFv was around $750 \mathrm{bp}$. The DNA ladder of $100 \mathrm{bp}$ was used for size indication (lane M).

\section{Cloning of scFv DNA and screening of phage-displayed scFv}

The amplified $\mathrm{scFv}$ was ligated into the pCANTAB5E expression vector. The ligated product was transformed into E. coli TGI and rescued by the M13K07 helper phage. The single-chain antibody was then expressed as an anchored protein on the tip of the phage particle. Random colonies of E. coli were picked from an SOBAG agar plate and phagemid DNA was isolated. Amplification was carried out using R1 and R2 primers to detect scFv (Figure 2). 


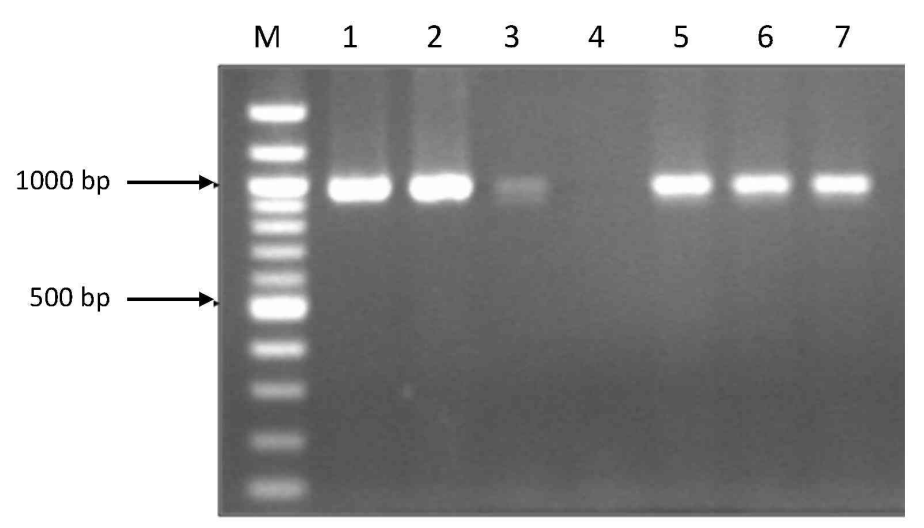

Figure 2. Detection of scFv using PCR method. Seven colonies were randomly chosen for PCR detection using $\mathrm{R} 1$ and R2 primers (Pharmacia, Sweeden). PCR was performed at $95^{\circ} \mathrm{C}$ for 5 minutes, followed by 30 cycles at $94^{\circ} \mathrm{C}$ for 1 minute, $55^{\circ} \mathrm{C}$ for 2 minutes and finally at $72^{\circ} \mathrm{C}$ for 2 minutes. Five microliters of each PCR products were electrophoresed on a $1 \%$ agarose gel in $0.5 \mathrm{X}$ TAE and stained with ethidium bromide. Lane $M=100-\mathrm{bp}$ DNA ladder (New England Biolabs, USA). Bands were detected in all samples with the same sizes, about $100 \mathrm{bp}$; lane 1-2 (double stranded DNA) and lane 3,5, 6, and $7=$ single stranded DNA. Lane $4=$ Negative control where bacterial colony carrying pCANTAB 5E vector alone was used for the PCR detection.

\section{Panning to select the phages displaying MCF-7-positive recombinant antibodies}

The phage antibodies were tested for MCF-7 specific binding after the first and second rounds of panning. The phage ELISA showed an increased signal in the final round of panning (Figure 3). The phage antibody gave a very weak signal against MCF-7 before panning and increased significantly after a number of rounds of panning (data not shown). It has been demonstrated that repeating biopanning enriches bacteriophages carrying the $\mathrm{scFv}$ sequences. After panning, 48 antigen-positive phage clones were randomly picked and screened by ELISA. The 4 clones D11, B7, B1 and A10 showed the strongest signal, and one out of the 4 clones, clone B7, was selected for further study (Table 1). Following selection, the strongest positive clone $\mathrm{B} 7$ was used to compare antigen binding reactivity with the Mab derived from the $\mathrm{C} 3 \mathrm{~A} 8$ parental hybridoma. It showed that $\mathrm{C} 3 \mathrm{~A} 8 \mathrm{scFv}$ could retain the binding specificity of the parent Mab, since the ratio for the parent Mab was 7.577, while 5.625 for $\mathrm{C} 3 \mathrm{~A} 8 \mathrm{scFv}$ (Table 2).

\section{DNA sequence analysis}

The phagemid derived from clone B7 was used for DNA sequencing, and the results showed that the $\mathrm{V}_{\mathrm{H}}$ and $\mathrm{V}_{\mathrm{L}}$ DNAs of scFv DNA were about $340 \mathrm{bp}$ and $320 \mathrm{bp}$, respectively (Figure 4). The CDR regions in $\mathrm{V}_{\mathrm{H}}$ and $\mathrm{V}_{\mathrm{L}}$ amino acids were determined using KABAT and Chothia numbering as represented in Figure 5.

\section{Expression of soluble antibody from cloned scFv fragments}

E. coli $\mathrm{HB} 2151$ cells were infected with strong positive phage obtained after two rounds of panning. The amber stop codon was recognized between the scFv and the M13 gene III pro- 
tein, resulting in the production of soluble scFv by E. coli. The soluble scFv were directed to the periplasmic space by an NH2-terminal gene III protein leader sequence. The peptide epitope E-tag incorporation at the $\mathrm{COOH}$-terminal allowed the detection of anti-E-tag antibody. Upon induction with isopropyl-D-thiogalactopyranoside (IPTG), the culture extracts were subjected to SDS-PAGE and Western blotting. An immunoreactive band with an apparent molecular mass of about $32 \mathrm{kDa}$ was detected in the periplasmic and supernatant extracts (Figure 6). The scFv recombinant protein was not observed in the noninduced culture (Figure 7).

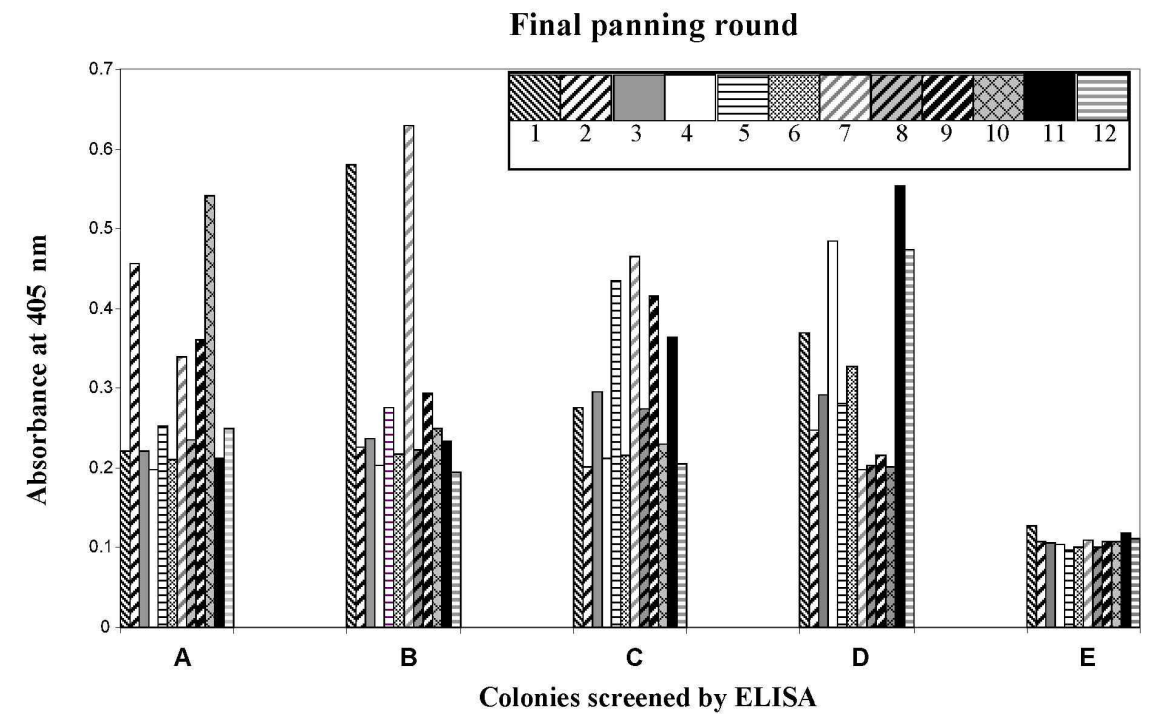

Figure 3. Performance of 48 preselected positive clones (columns A to D) and negative control (column E) were screened for binding activity against MCF-7 by phage ELISA. Each column represents the ELISA signal from an individual clone isolated after second round of biopanning. Four clones (A10, B1, B7, and D11) that showed the highest representative were selected for further study.

Table 1. Reactivity of scFv antibodies against MCF-7.

\begin{tabular}{llcc}
\hline ELISA & \multicolumn{2}{c}{ scFv antibodies } & Negative control \\
\cline { 2 - 3 } OD & From supernatant (after 20 X concentrated) & From periplasmic extract & \\
\hline & 0.706 & 0.480 & 0.106
\end{tabular}

Cell ELISA results of the scFv antibodies (derived from periplasmic and supernatant extracts) against MCF-7 that was expressed by positive phage recombinants in Escherichia coli strain HB2151.

Table 2. Screening for strongest phage recombinants displaying $\mathrm{scFv}$ antibodies.

\begin{tabular}{lccccc}
\hline ELISA & \multicolumn{4}{c}{ No. of strong positive clones } & Negative control \\
\cline { 2 - 5 } OD & $1(\mathrm{D} 11)$ & $2(\mathrm{~B} 7)$ & $3(\mathrm{~B} 1)$ & $4(\mathrm{~A} 10)$ & \\
\hline & 0.554 & 0.630 & 0.580 & 0.541 & 0.112 \\
\hline
\end{tabular}

Screening for phage positive clones displaying antigen binding antibodies against MCF-7 cells before production of soluble antibodies in Escherichia coli HB2151. All four clones, which showed the highest absorbance, were set aside for further study. 


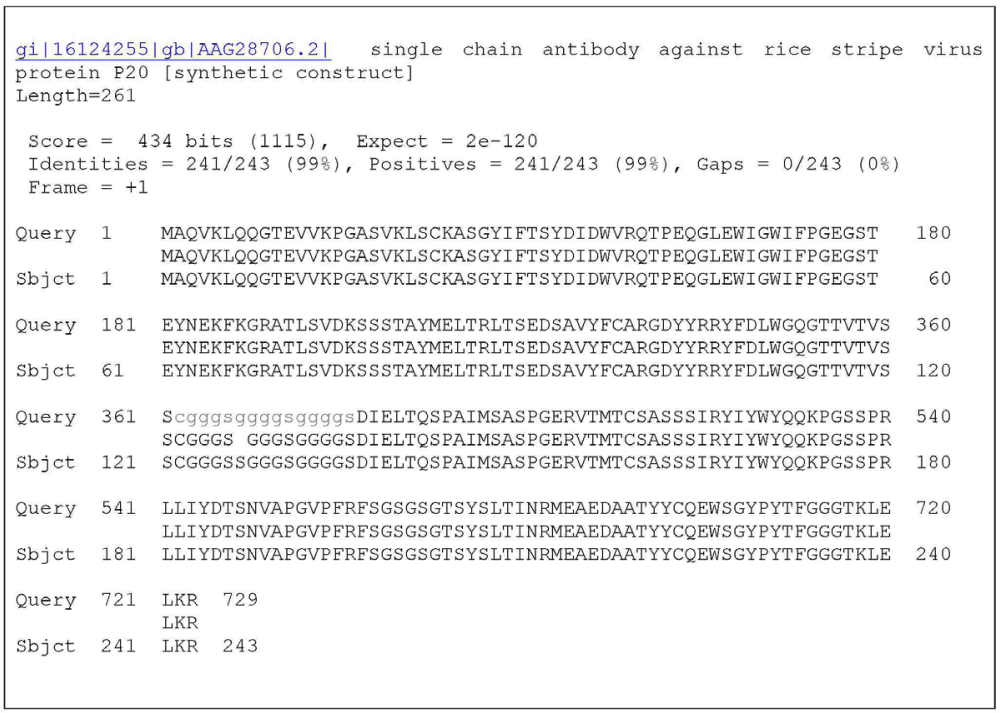

Figure 4. BLAST-P search hit for anti-MCF7 scFv against PDB (protein databank). The results show that the antiMCF7 is similar to a single chain antibody against rice stripe virus protein P20 (synthetic construct) at a similarity of $99 \%$ (gi|16124255|gb|AAG28706.2|).

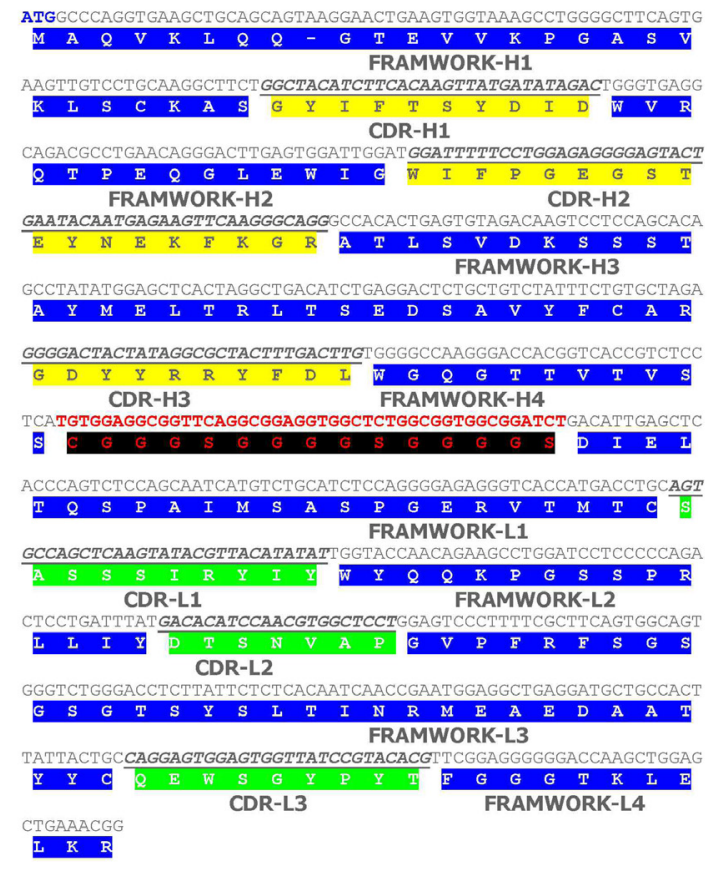

Figure 5. DNA and protein sequences for $\mathrm{V}_{H}$ and $\mathrm{V}_{\mathrm{L}}$ chains. Both $\mathrm{V}_{\mathrm{H}}$ and $\mathrm{V}_{\mathrm{L}}$ chains were obtained from FIRST BASE Laboratories Sdn. Bhd and the TRANSLATE program is used to translate into protein sequences. The 3 CDRs for both the chains were obtained using KABAT numbering and the CDR sequences are shown in yellow and green highlight. 


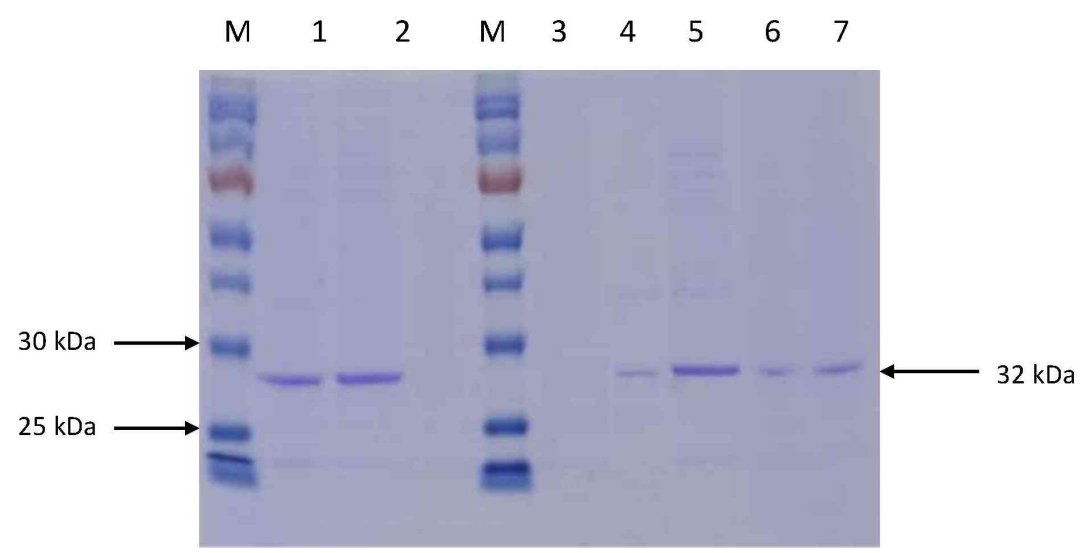

Figure 6. SDS-PAGE analysis for the detection of soluble $\mathrm{C} 3 \mathrm{~A} 8 \mathrm{scFv}$ antibodies from periplasmic and supernatant extracts. Lanes 1 and 2 = periplasmic extracts. Lane $3=$ extract from negative clone; pCANTAB 5E phagemid vector without insert (blank). Lanes 4 to $7=$ supernatant extracts. Lane $M=$ PageRuler ${ }^{\mathrm{TM}}$ Prestained Protein Ladder (Fermentas).
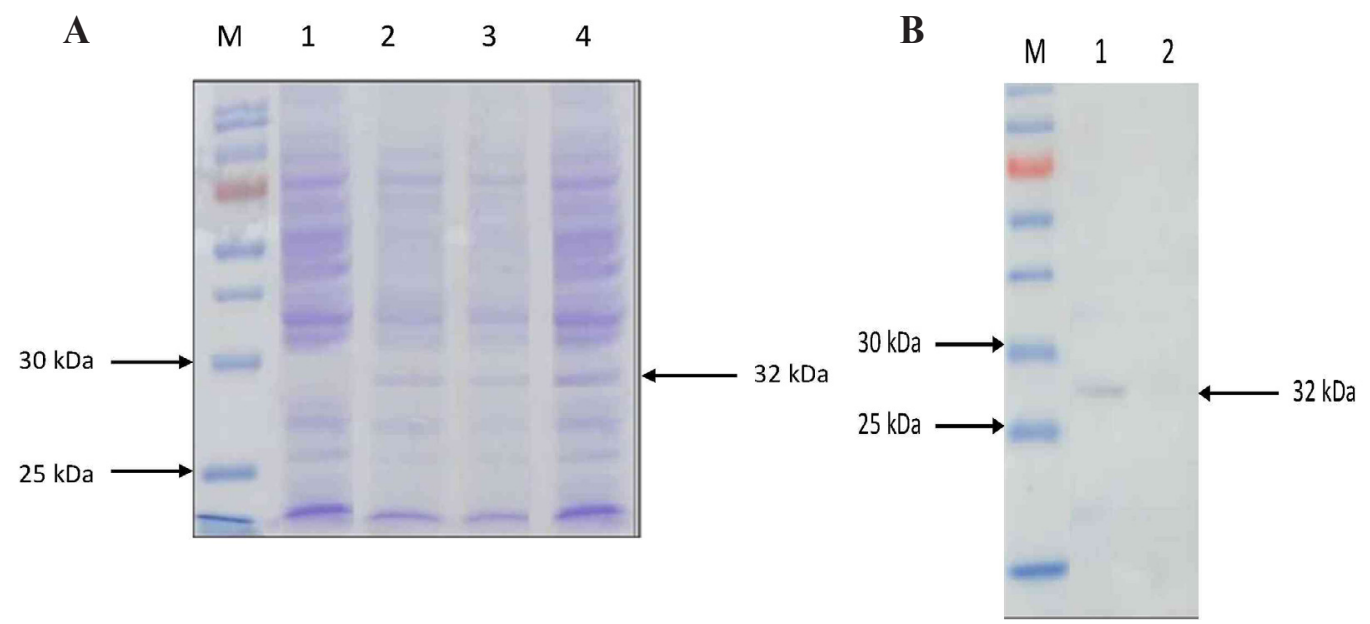

Figure 7. A. Lane $1=$ crude extract from negative clone; pCANTAB $5 \mathrm{E}$ phagemid vector without insert (blank). Lanes 2 to $4=$ SDS-PAGE for detection of insoluble C3A8 scFv from crude cells extract. B. Lane $1=$ Western blotting of scFv antibody detected with HRP/anti-E tag antibody. Inserts were grown in the expression vector pCANTAB 5E. One milliliter induced culture was centrifuged at $10000 \mathrm{~g}$ for $3 \mathrm{~min}$ and resuspended in $100 \mathrm{~mL}$ of $2 \mathrm{X}$ sample buffer prior to preheat at $95^{\circ} \mathrm{C}$ for $5 \mathrm{~min}$. Next, the denatured protein separated by SDS-PAGE before being transferred onto PVDF membrane. The membrane then probed using HRP/anti-E tag antibody and finally developed using 4-CN substrate. A $32-\mathrm{kDa}$ band was visualized on the membrane as anticipated. Lane $M=$ PageRuler ${ }^{\mathrm{TM}}$ Prestained Protein Ladder (Fermentas).

\section{Quantification of the scFv fragment specificity against MCF-7 by indirect ELISA}

After the expression of soluble scFv in E. coli HB2151, all three different fractions were analyzed by ELISA and Western blotting to confirm the presence and reactivity of scFv. 
The results showed that $\mathrm{scFv}$ obtained from the supernatant and periplasmic extract expressed high binding activity towards MCF-7, whereas no significant binding signal was obtained with whole-cell extracts.

\section{DISCUSSION}

The emerging technology of recombinant antibodies has brought new promising approaches towards expression of antibody fragments using phage display system in the field of cancer therapy because of its wide advantages over hybridoma technology, such as generating high-affinity antibodies with increased specificity, and involving quick and economical procedures (Shadidi and Sioud, 2001; Govorko et al., 2001). In the present study, we constructed the $\mathrm{scFv}$ antibodies using hybridoma cells through phage display technology. Normally, the concentration and purity of mRNA derived from C3A8 hybridoma are crucial for sufficient gene amplification of heavy and light chain. The amplified $V_{H}$ and $V_{L}$ DNAs measured about $340 \mathrm{bp}$ and $320 \mathrm{bp}$ respectively. These anticipated molecular weights were confirmed by DNA sequencing of $\mathrm{scFv}$ genes. According to DNA sequencing, the amino acids of $\mathrm{CDR}$ regions in $\mathrm{V}_{\mathrm{H}}$ and $\mathrm{V}_{\mathrm{L}}$ were determined using KABAT numbering. It is important that the concentration of the two DNA chains be the same to construct a successful scFv. Therefore, we compared the intensity of bands with the known quantities on a DNA ladder (data not shown). This concentration was then employed in the subsequent PCR, which yielded the single-chain variable fragment DNA of $750 \mathrm{bp}$. More than one assembly PCR was performed to obtain a sufficient amount of pure scFv DNA.

The amplified $\mathrm{V}_{\mathrm{H}}$ and $\mathrm{V}_{\mathrm{L}}$ genes were joined with a neutral linker and expressed as a single polypeptide chain; however, the joining of the $\mathrm{V}_{\mathrm{H}}$ and $\mathrm{V}_{\mathrm{L}}$ genes together with the peptide linker enables both of the regions to associate intra-molecularly and stabilizes variable domain combinations that react weakly (Krebber et al., 1997). Therefore, the flexible peptide linker consisting of 15-amino acid $\left(\mathrm{Gly}_{4} \mathrm{Ser}\right)_{3}$ was used to bridge the $3.5 \mathrm{~nm}$ gap between the carboxy-terminus of the $\mathrm{V}_{\mathrm{H}}$ chain and the amino terminus of the $\mathrm{V}_{\mathrm{H}}$ and $\mathrm{V}_{\mathrm{L}}$ chain. This construction facilitated the chain pairing and minimized the refolding and aggregation problems encountered (Whitlow et al., 1991). Apparently, the affinity and stability of scFv antibodies

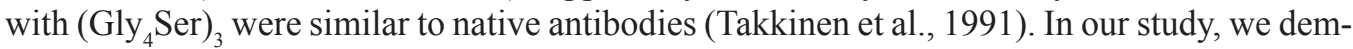
onstrated that the engineered $\mathrm{C} 3 \mathrm{~A} 8 \mathrm{scFv}$ could preserve the reactivity of their parental Mab.

The single chain antibody was expressed on the tip of the filamentous phage as a membrane-anchored protein. This provided antibody selection in a very efficient way as well as isolating the best candidate for $\mathrm{scFv}$ antibodies. We determined the best four candidates from our sample, and the selected positive phage recombinants were used to infect expression host $E$. coli HB2151. The phage antibodies showed high specificities against MCF-7 either as a component of the phage or soluble antibodies. We incorporated pCANTAB 5E as a g3p leader sequence that facilitated the direct transport of the $\mathrm{scFv}$ to the inner membrane of $E$. coli. In concordance with other studies, we demonstrated that the soluble $\mathrm{scFv}$ antibodies accumulated in the periplasm of E. coli $\mathrm{HB} 2151$ upon extended incubation (Hoogenboom et al., 1991). The scFv antibodies were visualized as a $32 \mathrm{kDa}$ band, and this indicated that most scfv antibodies were produced by the clones as inclusions or insoluble forms. The inclusion bodies were harvested and the aggregated proteins were solubilized with $8 \mathrm{M}$ urea to obtain the active $\mathrm{scFv}$ (Cao et al., 2005). In the present study, we showed an efficient means of obtaining large amounts of scFv. 
In summary, recent advances in antibody engineering such as phage display technology can be used to develop clinically relevant anti-MCF-7 antibody fragment to achieve optimal tumor localization and also to serve as a targeting vehicle for therapeutic applications in breast cancer.

\section{ACKNOWLEDGEMENTS}

Research supported by the Ministry of Science, Technology and Environment of Malaysia (\#IRPA-5495304). We thank Prof. Dr. Sazaly Abu Bakar, Department of Medical Microbiology, University Malaya Medical Centre, Kuala Lumpur, for technical advice.

\section{REFERENCES}

Adams GP, Schier R, McCall AM, Crawford RS, et al. (1998). Prolonged in vivo tumour retention of a human diabody targeting the extracellular domain of human HER2/neu. Br. J. Cancer 77: 1405-1412.

Ali AM, Ong BK, Yusoff K and Hamid M (1996). Generation of stable hybridoma clone secreting monoclonal antibody against breast cancer. Asia Pac. J. Mol. Biol. Biotechnol. 4: 123-131.

Boss MA, Kenten JH, Wood CR and Emtage JS (1984). Assembly of functional antibodies from immunoglobulin heavy and light chains synthesised in E. coli. Nucleic Acids Res. 12: 3791-3806.

Cao P, Tang XM, Guan ZB, Diao ZY, et al. (2005). Production and characterization of a bacterial single-chain antibody fragment specific to B-cell-activating factor of the TNF family. Protein Expr. Purif. 43: 157-164.

Chaudhary VK, Batra JK, Gallo MG, Willingham MC, et al. (1990). A rapid method of cloning functional variable-region antibody genes in Escherichia coli as single-chain immunotoxins. Proc. Natl. Acad. Sci. U. S. A. 87: 1066-1070.

Choo AB, Dunn RD, Broady KW and Raison RL (2002). Soluble expression of a functional recombinant cytolytic immunotoxin in insect cells. Protein Expr. Purif. 24: 338-347.

Chowdhury PS, Viner JL, Beers R and Pastan I (1998). Isolation of a high-affinity stable single-chain Fv specific for mesothelin from DNA-immunized mice by phage display and construction of a recombinant immunotoxin with antitumor activity. Proc. Natl. Acad. Sci. U. S. A. 95: 669-674.

Finlay WJ, Shaw I, Reilly JP and Kane M (2006). Generation of high-affinity chicken single-chain Fv antibody fragments for measurement of the Pseudonitzschia pungens toxin domoic acid. Appl. Environ. Microbiol. 72: 3343-3349.

Garet E, Cabado AG, Vieites JM and Gonzalez-Fernandez A (2010). Rapid isolation of single-chain antibodies by phage display technology directed against one of the most potent marine toxins: Palytoxin. Toxicon 55: 1519-1526.

Govorko D, Cohen G and Solomon B (2001). Single-chain antibody against the common epitope of mutant p53: isolation and intracytosolic expression in mammalian cells. J. Immunol. Methods 258: 169-181.

Gram H, Marconi LA, Barbas CF, III, Collet TA, et al. (1992). In vitro selection and affinity maturation of antibodies from a naive combinatorial immunoglobulin library. Proc. Natl. Acad. Sci. U. S. A. 89: 3576-3580.

Griffiths AD and Duncan AR (1998). Strategies for selection of antibodies by phage display. Curr. Opin. Biotechnol. 9: 102-108.

Ho M, Nagata S and Pastan I (2006). Isolation of anti-CD22 Fv with high affinity by Fv display on human cells. Proc. Natl. Acad. Sci. U. S. A. 103: 9637-9642.

Hoogenboom HR, Griffiths AD, Johnson KS, Chiswell DJ, et al. (1991). Multi-subunit proteins on the surface of filamentous phage: Methodologies for displaying antibody (Fab) heavy and light chains. Nucl. Acid. Res. 19: 41334137.

Hu S, Shively L, Raubitschek A, Sherman M, et al. (1996). Minibody: A novel engineered anti-carcinoembryonic antigen antibody fragment (single-chain Fv-CH3) which exhibits rapid, high-level targeting of xenografts. Cancer Res. 56: 3055-3061.

Huston JS, Levinson D, Mudgett-Hunter M, Tai MS, et al. (1988). Protein engineering of antibody binding sites: recovery of specific activity in an anti-digoxin single-chain Fv analogue produced in Escherichia coli. Proc. Natl. Acad. Sci. U. S. A. 85: 5879-5883.

Huston JS, George AJ, Adams GP, Stafford WF, et al. (1996). Single-chain Fv radioimmunotargeting. Q. J. Nucl. Med. 40: 320-333.

Kontermann RE and Muller R (1999). Intracellular and cell surface displayed single-chain diabodies. J. Immunol. Methods 226: $179-188$. 
Krebber A, Bornhauser S, Burmester J, Honegger A, et al. (1997). Reliable cloning of functional antibody variable domains from hybridomas and spleen cell repertoires employing a reengineered phage display system. J. Immunol. Methods 201: 35-55.

Marasco WA and Dana JS (1998). Antibodies for targeted gene therapy: extracellular gene targeting and intracellular expression. Adv. Drug Deliv. Rev. 31: 153-170.

Pande J, Szewczyk MM and Grover AK (2010). Phage display: concept, innovations, applications and future. Biotechnol. Adv. 28: 849-858.

Shadidi M and Sioud M (2001). An anti-leukemic single chain Fv antibody selected from a synthetic human phage antibody library. Biochem. Biophys. Res. Commun. 280: 548-552.

Takkinen K, Laukkanen ML, Sizmann D, Alfthan K, et al. (1991). An active single-chain antibody containing a cellulase linker domain is secreted by Escherichia coli. Protein Eng. 4: 837-841.

Whitlow M, Howard AJ, Finzel BC, Poulos TL, et al. (1991). A metal-mediated hydride shift mechanism for xylose isomerase based on the 1.6 A Streptomyces rubiginosus structures with xylitol and D-xylose. Proteins 9: 153-173.

Zhang JL, Gou JJ, Zhang ZY, Jing YX, et al. (2006). Screening and evaluation of human single-chain fragment variable antibody against hepatitis B virus surface antigen. Hepatobiliary. Pancreat. Dis. Int. 5: 237-241. 